Analitika: Jurnal Magister Psikologi UMA, Vol. 12 (2) Desember (2020)

ISSN: 2085-6601 (Print), ISSN: 2502-4590 (Online)

DOI: http://doi.org/10.31289/analitika.v12i2.3288

\title{
ANALITIKA
}

Jurnal Magister Psikologi UMA

Available online http://ojs.uma.ac.id/index.php/analitika

\section{Menguji Konsistensi Korelasi Work Engagement dengan Intensi Turnover: Studi Meta-Analisis}

\section{Test the Consistency of Work Engagement Correlations with Turnover Intention: Meta-Analysis Study}

\author{
Heby Em Arta* \\ Bidang Studi Psikologi Industri \& Organisasi, Program Studi Magister Psikologi Profesi, \\ Fakultas Psikologi, Universitas Surabaya, Indonesia
}

Diterima: 4 Januari 2020, disetujui: 27 Desember 2020, dipublish: 30 Desember 2020

*Corresponding author: E-mail: hebyemarta895@gmail.com

\begin{abstract}
Abstrak
Intensi turnover dipengaruhi oleh berbagai faktor. Banyak penelitian yang mengungkap dan menguji anteseden munculnya intensi turnover. Chang, et al. (2013) mereview lebih dari 20 studi tentang intensi turnover dan menemukan variabel keterlibatan kerja merupakan variabel yang paling sering diteliti dalam kaitannya dengan intensi turnover.Penelitian ini menguji korelasi antara Work Engagement dan intensi turnover yang diperoleh dari berbagai penelitian pada 2013-2017 menggunakan metode meta-analisis. Sampel yang digunakan terdiri dari 14 jurnal penelitian yang diambil dari database online. Analisis dilakukan dengan menggunakan dua artefak, koreksi pengambilan sampel kesalahan dan pengukuran kesalahan. Hasil penelitian menunjukkan bahwa korelasi antara Work Engagement dan intensi turnover pada artefak 1 adalah -0,25 dan pada artefak ke-2 adalah -0,27. Hasil ini membawa implikasi pada tataran praktek bahwa keterlibatan kerja adalah variabel yang sangat menentukan intensi turnover.
\end{abstract}

Kata Kunci: Keterlibatan kerja; Meta-analisis; Intensi turnover

\begin{abstract}
Turnover intention is influenced by various factors. Many studies reveal and test the antecedents of the emergence of turnover intentions. Chang, et al. (2013) reviewed more than 20 studies on turnover intentions and found that work engagement variables were the most frequently studied variables in relation to turnover intentions. This study examined the correlation between Work engagement and turnover intention derived from various studies in 20132017 using meta-analysis method. The used samples consisted from 14 research journal drawn from online databases. Analyses were conducted using two artefacts, correction on error sampling and on error measures. Results of the study showed that correlation between Work Engagement and turnover intention in the 1st artefact was $-0,25$ and in the second artefact was -0,27. This result aim that the work engagement is the most significat variable to predict the turnover intentions.
\end{abstract}

Keywords: Work engagement; Meta-analysis; Turnover intention

How to Cite: Arta, H.E. (2020). Menguji Konsistensi Korelasi Work Engagement dengan Intensi Turnover: Studi Meta-Analisis. Analitika: Jurnal Magister Psikologi UMA, 12 (2): 130 - 137 


\section{INTRODUCTION}

One very interesting theme to be studied and examined in the repertoire of industrial and organizational psychology is turnover. How important is turnover for an organization? Lots of research is done related to the antecedents and effects of turnover with a variety of settings and research subjects (Hindiarto, 2017) According to (Hindiarto, 2017)various literatures and research results mention the practices of human resource management carried out by organizations to manage or control quality human resources in order to survive so that it will become one of the values of competitive advantage for the organization. This shows how important turnover is for an organization.

The concept of comprehensive turnover was developed by (Agoi, 2015), namely the cessation of an individual from an organization's membership either on its own accord or because it was dismissed by the organization. If the organization does not manage turnover effectively it can have a negative impact on the organization itself. (Gilham, 2012) suggest that turnover has a very expensive impact on the organization. According to one calculation, the losses caused by employee turnover in American companies can reach \$5 trillion per year. These costs include: costs for paying temporary substitute employees, fees for paying overtime as long as replacement employees have not been obtained, fees for obtaining substitute employees and fees to make new employees competent as old employees leave.
The negative impact of turnover is not only on the economic and efficiency aspects, but also on the moral-social impact and productivity of the organization. Deeper, the problem of turnover actually gives the message that there are fundamental and complex issues that are occurring in the organization (Moka et al., 2015)

However, turnover does not always have a negative impact on the organization. (Baltagi \& Law, 2007) state that there is a positive side to turnover for organizations. With turnover, the organization has the opportunity to get new employees who are more skilled, more enthusiastic, more productive than the old employees who leave. Turnover is possible for organizations to save money, because the salary given to new employees is certainly smaller than the salary of employees who have had a longer working period. In addition, with the presence of new employees, organizations will benefit from new ideas raised by new employees.

This study aims to examine the relationship between work engagement and turnover intentions originating from various studies in 2013-2017 using the meta-analysis method. Based on the opinions expressed by (Zhu et al., 2019) and (Yuliawan \& Himam, 2015) then in this study the sample to be analyzed is a study that measures turnover intention and makes it a dependent variable and its measurement is done by the self report method using a Likert scale.

The emergence of turnover intentions is influenced by various factors. Many studies reveal and test the antecedents of the emergence of 
turnover intentions. (Caesens et al., 2016) found factors that influence the emergence of turnover intentions, namely: personal factors such as motivation, personality, and work engagement; job factors such as job autonomy; organizational factors such as organizational support, policies that are considered fair. Another opinion expressed by (Aamodt, 2009) who found in his research, that turnover intention is influenced by underemployment (lack of jobs), person-job fit, and person-fit organization. (Lu et al., 2016) suggest variables that are predictors of the emergence of turnover intentions are job autonomy, fair reward, social support and work engagement. (Shockley \& Singla, 2011) reviewed more than 20 studies on turnover intentions and found that work engagement variables were the most frequently studied variables in relation to turnover intentions.

(Lekhuleng, 2016) provides a definition that engagement is the presence of psychological bonds when working and performing roles within the organization. Gallup (in (Lopez \& Snyder, 2012)), defines work engagement as a bond that occurs between employees and organizations (workplaces), so that employees show concern for business continuity. (Saks, 2006), also revealed that the concept of work engagement can be harmonized with the SET (SocialExchange Theory) theory, where relationships that occur between employees and companies occur from a series of interactions that evolve with time with a sense of mutual benefit and mutual loyalty over a range certain conditions. Behavior that is antecedent in work engagement can be seen from the overall commitment, interest, involvement, enthusiasm of the individual in the work situation, which is in accordance with the goals of the organization and is predicted to increase the effectiveness of the organization. (Crawford et al., 2010).

Work engagement is different from organizational commitment. Organizational commitment is related to attitude and closeness to the organization. While engagement is not an attitude but a level where individuals have more attention in carrying out their roles in the work environment (Merissa, 2018). Work engagement is also different from employee involvement. A person is able to engage in a job both individually and in a team without being engaged in the work or organization where he works. But an employee who is engaged in practice will show involvement or participation when working.

\section{METHODOLOGY}

Studies in this meta-analysis are collected from several sources, namely: sciencedirect, springerlink and google with keywords Work engagement turnover intention. Journal search starts on 21 April 2018 and ends on 30 May 2018. 
Heby Em Arta, Menguji konsistensi korelasi Work Engagement dengan intensi Turnover

Figure 1. Study/research journal selection flow chart

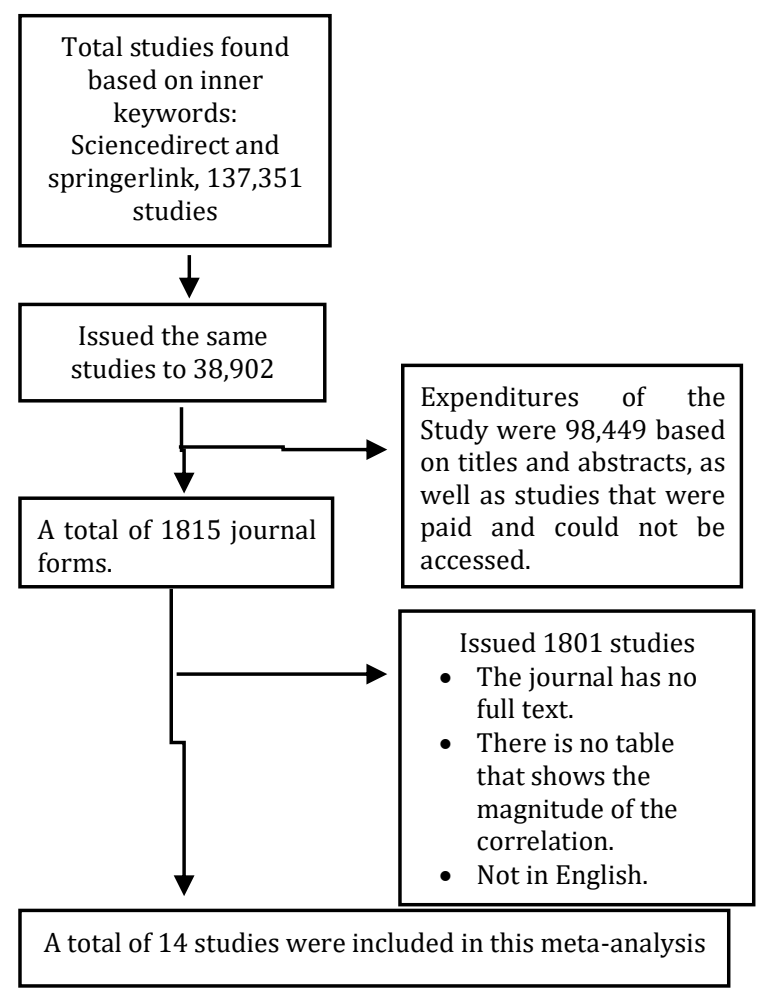

\section{RESULTS AND DISCUSSIONS}

The correlation between Work engagement and turnover intentions in this metaanalysis was found to have a Moderate effect size (see figure 2, the pooledeffect size value was $0.2500825978,(95 \% \mathrm{CI}=-0.275466$ to $0.224349 \mathrm{I} 2=97.4 \%)$. has a strong enough influence on turnover intentions. In addition, the egger value can be found at 1.64041 with a significance of 2.902468 ( $>0.05$ ), this result indicates that there is no publication bias (see figure 2).
Figure 2. Correlation meta-analysis plot
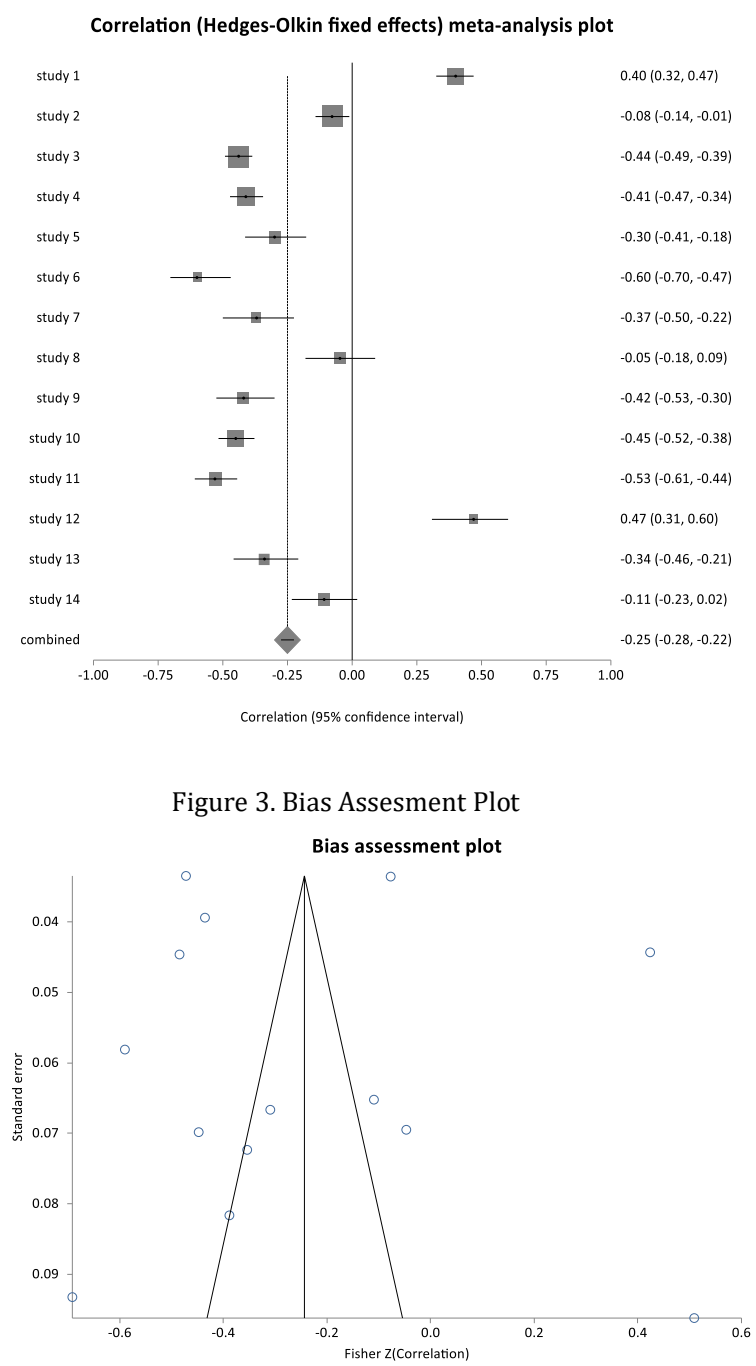

Tabel 1. The Information of study that included on metaanalysis

\begin{tabular}{|c|c|c|c|c|}
\hline Study & $\mathbf{N}$ & $\mathbf{r}$ & sign. & Scale \\
\hline Zhang, 2015 & 512 & 0,4 & 0,01 & UWES \\
\hline $\begin{array}{c}\text { Thirapatsakun, } \\
2014\end{array}$ & 890 & $-0,077$ & 0,05 & UWES \\
\hline $\begin{array}{l}\text { Lu Lu et al, } \\
2014\end{array}$ & 895 & $-0,44$ & 0,05 & UWES \\
\hline Caesens, 2014 & 647 & $-0,41$ & 0,01 & UWES \\
\hline Gupta, 2016 & 228 & $-0,3$ & 0,01 & UWES \\
\hline Agoi, 2015 & 118 & $-0,599$ & 0,01 & UWES \\
\hline Takawira, 2013 & 153 & $-0,37$ & 0,01 & UWES \\
\hline Taboli, 2015 & 210 & $-0,047$ & 0,05 & UWES \\
\hline $\begin{array}{l}\text { Shahpouri, } \\
2015\end{array}$ & 208 & $-0,42$ & 0,01 & UWES \\
\hline Camgoz, 2016 & 505 & $-0,45$ & 0,01 & UWES \\
\hline Oliveira, 2017 & 299 & $-0,53$ & 0,01 & UWES \\
\hline Erdil, 2014 & 111 & 0,469 & 0,01 & $\begin{array}{c}\text { Rich, Et al, } \\
2010\end{array}$ \\
\hline Simone, 2017 & 194 & $-0,34$ & 0,01 & UWES \\
\hline Babakus, 2017 & 238 & $-0,109$ & 0,01 & $\begin{array}{l}\text { oldenburg } \\
\text { Burnout } \\
\text { Inventory }\end{array}$ \\
\hline
\end{tabular}


Table 2. R values and confidence intervals

\begin{tabular}{|c|c|c|c|c|c|c|}
\hline Study & $\mathbf{N}$ & cor & Ap95 & & $\underline{\text { Se }}$ & V \\
\hline $\begin{array}{c}\text { Zhang, } \\
2015\end{array}$ & 512 & 0.4 & 0.32 & 0.470 & 0.423 & 0.0019 \\
\hline $\begin{array}{l}\text { Thirapat } \\
\text { sakun, } \\
2014\end{array}$ & 890 & -0.07 & 0.141 & -0.01 & -0.077 & 0.0011 \\
\hline $\begin{array}{l}\text { Lu Lu et } \\
\text { al, } 2014\end{array}$ & 895 & -0.44 & -0.49 & -0.38 & -0.472 & 0.0011 \\
\hline $\begin{array}{c}\text { Caesens, } \\
2014\end{array}$ & 647 & -0.41 & -0.47 & -0.34 & -0.435 & 0.0015 \\
\hline $\begin{array}{l}\text { Gupta, } \\
2016\end{array}$ & 228 & -0.3 & -0.41 & -0.17 & -0.309 & 0.0044 \\
\hline $\begin{array}{l}\text { Agoi, } \\
2015\end{array}$ & 118 & -0.59 & -0.70 & -0.46 & -0.691 & 0.0086 \\
\hline $\begin{array}{c}\text { Takawira } \\
, 2013\end{array}$ & 153 & -0.37 & -0.49 & -0.22 & -0.388 & 0.0066 \\
\hline $\begin{array}{c}\text { Taboli, } \\
2015\end{array}$ & 210 & -0.04 & -0.18 & 0.0889 & -0.047 & 0.0048 \\
\hline $\begin{array}{c}\text { Shahpour } \\
\text { i, } 2015\end{array}$ & 208 & -0.42 & -0.52 & -0.30 & -0.447 & 0.0048 \\
\hline $\begin{array}{c}\text { Camgoz, } \\
2016\end{array}$ & 505 & -0.45 & -0.51 & -0.377 & -0.484 & 0.0019 \\
\hline $\begin{array}{c}\text { Oliveira, } \\
2017\end{array}$ & 299 & -0.53 & -0.60 & -0.443 & -0.590 & 0.0033 \\
\hline $\begin{array}{l}\text { Erdil, } \\
2014\end{array}$ & 111 & 0.469 & 0.309 & 0.6027 & 0.5088 & 0.0092 \\
\hline $\begin{array}{c}\text { Simone, } \\
2017\end{array}$ & 194 & -0.34 & -0.45 & -0.20 & -0.354 & 0.0052 \\
\hline $\begin{array}{c}\text { Babakus, } \\
2017\end{array}$ & 238 & -0.10 & -0.23 & 0.018 & -0.109 & 0.0042 \\
\hline
\end{tabular}

Next is the result of calculation of population correlation variance, which reflects the deviation of the correlation results of each study with the average correlation of the whole study. The population correlation variance value obtained is equal to 0.019 which indicates that the correlation score for each study studied has a small deviation from the average correlation of the entire study.

The confidence interval is in the range of -0.727 to -0.192 , with SD 0.141 . By using a 95\% confidence interval, the average population correlation of -0.459 indicates that the research hypothesis is accepted, which means that the work engagement is a negative correlation that is very significant with turnover intentions. Analysis of the impact of sampling errors on the results of the study was $6.46 \%$. This indicates that the impact of sampling errors on the results of research in the population analyzed was very small.

From the results of the calculation above, it can be seen that the average correction of the measurement error of the dependent variable, both independent and independent, is 0.82 . The variance caused by measurement errors is 0,000845 which indicates that variations in measurement errors in each study are very small.

Population correlation coefficient after correction of measurement errors is equal to -0.56 . With a range of confidence intervals of -0.88 to -0.24 , the population correlation coefficient of -0.56 is still within the accepted value limit. The percentage of the impact of measurement errors on the measurement variance in the two variables studied was $10.7 \%$ which indicated a very small impact.

From the results of the analysis on two artifacts, namely correction of sampling errors and correction of measurement errors above, the proposed hypothesis is shown, namely there is a negative correlation between work engagement and turnover intentions accepted. The correlation coefficient of 0.46 and the variance of 0.02 in the calculation of the correction of sampling errors shows that the research population analyzed in this study has an almost homogeneous sample of employees, both from government organizations, hospitals and the private sector. against measurement errors, the correlation coefficient is -0.56 and the correlation variance caused by a 
measurement error of only 0.000845 indicates that the measuring instrument used on both variables can be trusted. This shows that all studies use a measuring instrument with almost the same construct. Variable work engagement is measured by the approach as a whole and not per aspect. The turnover intention variable is measured by the same construct, which is the measurement of intention rather than the actual turnover. The high number of population correlation coefficients is also reinforced by the number of effects of measurement errors on the variance of research results of $10.7 \%$. These results certainly reinforce the findings of the research and the theories put forward by the researchers stating that turnover intentions are closely related to the level of work engagement perceived by employees (Harter et al., 2002).

(Shahpouri et al., 2016) suggest that employees joining an organization certainly carry a lot of expectations such as expectations about salaries, working conditions, opportunities for growth and organizational culture that are in harmony with personal values. But if those expectations are not met, it will cause low work engagement and as a result employee will leave the organization.

Although there are various other variables which are antecedents of the emergence of turnover intentions, a strong negative correlation between work engagement and turnover intention indicates that work engegement is a variable that greatly influences employee turnover intentions. As stated by
(Aamodt, 2009) that of the 7 causes of an employee leaving the organization, the biggest factor is the low work engagement. So, if the organization wants to minimize the turnover rate, then a strategy to improve work engagement can be done. As said by (Shockley \& Singla, 2011) that by knowing the antecedents of turnover intentions, organizations can develop appropriate and effective interventions.

The results of this meta-analysis also answer the problems raised earlier that there are quite high variations on the results of the correlation between turnover intentions and work engagement in various studies that become research data. That even though various studies found negative correlations with varying numbers, the two variables did have very significant negative correlations. Of course, this result has implications at the practice level that work engagement is a variable that greatly determines turnover intentions.

\section{CONCLUSIONS}

This meta-analysis study provides information that work engegement has a very significant negative correlation with turnover intentions. This very significant correlation is obtained because of the small errors in sampling because it uses subjects that have relatively the same status even though they come from various types of organizations, and the small error in measuring variables because they use the same construct in compiling a measuring instrument. The results of this study are expected to be able to answer doubts both from the 
theoretical and practical aspects of the inconsistencies of research results related to the correlation between work engagement and turnover intentions.

The results of this study for the practical domain can be a major foothold for organizations that to minimize turnover intentions, organizations can develop strategies to increase work engagement for their employees. In the scientific domain, the results of this study can be the basis for the development of further studies, namely with relatively homogeneous samples and the use of measuring instruments with the same construct will produce more convincing findings. Another thing that can be developed is by examining the results of research on work engagement measured by a specific method of assessment in each aspect.

\section{REFERENCES}

Aamodt, M. G. (2009). Industrial Organizational Psychology: An Applied Approach. http://gen.lib.rus.ec/book/index.php?md5 $=4725 \mathrm{~A}_{4} \mathrm{BBA} 2 \mathrm{E}_{9} \mathrm{DoEDC} 9 \mathrm{~A}_{59} \mathrm{Fo}_{5} \mathrm{ACoE}_{57}$ $\mathrm{B} \%{ }_{7} \mathrm{D}$

Agoi, L. F. (2015). Effect of work engagement on employee turnover intention in Public Sector, Kenya. International Journal of Economics, Commerce and Management United Kingdom, 3(12), 426-440. http://ijecm.co.uk/

Baltagi, B. H., \& Law, S. H. (2007). D Epartment of E Conomics F Inancial D Evelopment, O Penness and I Nstitutions: E Vidence From $\mathrm{P}$ Anel D Ata. Corporate Governance, 07.

Caesens, G., Stinglhamber, F., \& Marmier, V. (2016). The curvilinear effect of work engagement on employees' turnover intentions. International Journal of Psychology, 51(2), 150-155. https://doi.org/10.1002/ijop.12131

Crawford, E. R., LePine, J. A., \& Rich, B. L. (2010). Linking job demands and resources to employee engagement and burnout: A theoretical extension and meta-analytic test. Journal of Applied Psychology, 95(5), 834-848. https://doi.org/10.1037/aoo19364

Gilham, C. A. (2012). The nature of work-family conflict and its relationship with psychological health outcomes. 1-68.

Harter, J. K., Schmidt, F. L., \& Hayes, T. L. (2002). Business-unit-level relationship between employee satisfaction, employee engagement, and business outcomes: A meta-analysis. Journal of Applied Psychology, $\quad 87(2), \quad$ 268-279. https://doi.org/10.1037/0021-9010.87.2.268

Hindiarto, F.-. (2017). Menguji Konsistensi Korelasi Job Satisfaction dengan Intensi Turnover: Studi Meta-Analisis. Buletin Psikologi, 25(2). https://doi.org/10.22146/buletinpsikologi.1 8203

Lekhuleng, B. (2016). Person-Organisation-Fit and Turnover Intention. March.

Lopez, S. J., \& Snyder, C. R. (2012). The Oxford Handbook of Positive Psychology, (2 Ed.). The Oxford Handbook of Positive Psychology, (2 Ed.), 1-742. https://doi.org/10.1093/oxfordhb/97801951 87243.001.0001

Lu, L., Lu, A. C. C., Gursoy, D., \& Neale, N. R. (2016). Work engagement, job satisfaction, and turnover intentions: A comparison between supervisors and linelevel employees. International Journal of Contemporary Hospitality Management, 28(4), 737-761. https://doi.org/10.1108/IJCHM-o7-20140360

Merissa, B. (2018). Pengaruh Work Engagement Terhadap Turnover Intention Melalui Job Satisfaction Sebagai Variabel Mediasi Pada PT. Lotte Shopping Indonesia Sidoarjo. Jurnal Agora, 6(1), 1-9. http://publication.petra.ac.id/index.php/ manajemen-bisnis/article/view/6485

Moka, S., Pande, M., Rani, M., Gakhar, R., Sharma, M. M., Rani, J., Bhaskarwar, A. N., Autelitano, F., Giuliani, F., Qureshi, M. N., Ghosh, S., Shiying, L., Wingtat, H., Zhen, L., Harvey, J., Kendall, A., Saboori, A., Sonar, S. S., Kategaonkar, A. H., ... Ding, G. K. C. (2015). No Title. Construction and Building Materials, 4(1), $1-8$.

http://www.ncbi.nlm.nih.gov/pubmed/172 89255\%oAhttp://dx.doi.org/10.1016/j.jclepr o.2011.10.008\%oAhttp://www.uwaba.or.tz/ 
Heby Em Arta, Menguji konsistensi korelasi Work Engagement dengan intensi Turnover

National_Road_Safety_Policy_September_ 2009.pdf\%oAhttp://dx.doi.org/10.1016/j.re sconrec.2011.03.010\%oAhttp://dx.doi.org/1 $0.1016 /$ j.pecs.20

Saks, A. M. (2006). Antecedents and consequences of employee engagement. Journal of Managerial Psychology, 21(7), 6oo-619.

https://doi.org/10.1108/0268394061069016 9

Shahpouri, S., Namdari, K., \& Abedi, A. (2016). Mediating role of work engagement in the relationship between job resources and personal resources with turnover intention among female nurses. Applied Nursing Research, 30, 216-221. https://doi.org/10.1016/j.apnr.2015.10.008

Shockley, K. M., \& Singla, N. (2011). Reconsidering work-family interactions and satisfaction: A meta-analysis. Journal of Management, 37(3), 861-886. https://doi.org/10.1177/0149206310394864

Yuliawan, T. P., \& Himam, F. (2015). The Grasshopper Phenomenon: Studi Kasus Terhadap Profesional yang Sering Berpindah - pindah Pekerjaan. 34(1), 7688.

Zhu, C., Chen, L., Ou, L., Geng, Q., Jiang, W., Lv, X., Wu, X., Ci, H., Liu, Q., Yao, Y., Pentadbiran, P., Persekutuan, K., Kami, R., Ketua, S., Kementerian, S., Persekutuan, J., Pentadbiran, S., Kerajaan, S., Berkanun, B., ... Flynn, D. (2019). No Title. $\quad A \gamma \alpha \eta, \quad 8(2), \quad 2019$. https://doi.org/10.22201/fq.18708404e.200 $4 \cdot 3.66178$ 